\title{
COLD WAR AND RELIGION: THE PROTESTANTISM AND THE SUPERPOWERS WORKSHOP
}

\author{
Emily B. Baran \\ Middle Tennessee \\ State University
}

\author{
Эмици Б. Баран \\ Университет \\ штата Теннесси
}

E-mail: emily.baran[at]mtsu.edu

Copyright: (C) 2015 Baran. This is an open-access publication distributed under the terms of the Creative Commons Attribution License, which permits unrestricted use, distribution, and reproduction in any medium, provided the original author and source, the Tractus Aevorum journal, are credited.

\section{"ХОМОДНАЯ ВОЙНА" И РЕАИГИЯ: СЕМИНАР О ЗНАЧЕНИИ ПРОТЕСТАНТИЗМА В КОНТЕКСТЕ ПРОТИВОСТОЯНИЯ СУПЕРДЕРКАВ}

The workshop, "Protestantism and the Superpowers: Mission, Spirituality, and Prayer in the USA and USSR," took place on September 27, 2014. Hosted by the University of Leicester, the event was organized by Uta Balbier (King's College), Miriam Dobson (University of Sheffield), and Zoe Knox (University of Leicester). The British Association for Slavonic and East European Studies and the Institute of North American Studies (King's College) provided additional funding support.

Academic interest in religion in the modern world, and in particular religious culture and identity, has grown in recent decades, mirroring the broader shift toward cultural history across the historical discipline. Scholars have also begun to pay closer attention to religion's global and transnational dimensions. This workshop extends this new emphasis into the study of the Cold War.

Panelists addressed shifting attitudes within the American evangelical community toward the so-called "Evil Empire." For many evangelicals, the Soviet Union and communist ideology represented an existential threat that also had apocalyptic implications. Daniel L. Smith-Christopher charted how Protestants interpreted (and reinterpreted) New Testament imagery of "swords" and "plowshares" in the context of American foreign policy objectives. Axel Schäfer discussed how conservative Protestants engaged with both American foreign policy and their own missionary objectives in the early Cold War. Uta Balbier and Emily Baran explored the critical importance of Billy Graham in articulating an American evangelical perspective on the Cold War. Balbier highlighted his evolving attitude toward the 
Soviet Union, while Baran spotlighted Graham's controversial 1982 visit to Moscow at the height of tensions between the United States and the USSR.

Workshop participants also considered the intersection of religion and the pursuit of world peace. Indeed, Billy Graham's 1982 visit included a keynote address at an international conference of religious clergy in support of peace and against nuclear war. Dianne Kirby went beyond the Protestant focus of the workshop to examine President Truman's failed attempt to harness the ecumenical movement for the promotion of his foreign policy. Riho Altnurme discussed theological support for the peace movement within the Protestant churches of Soviet Estonia. His paper suggests that scholars not dismiss the peace movement as a one-sided manipulation of church policy by state authorities. In this regard, it invites comparison to Kirby's exploration of Truman, in particular Truman's solicitations of support from religious authorities for his stated goal of world peace.

As Altnurme's paper suggests, the Cold War had a profound impact on theology and religious practice on the other side of the Iron Curtain as well. Two other panelists addressed this issue. Miriam Dobson analyzed private and public attitudes toward Protestant minorities by Soviet authorities in the post-Stalin era. Lastly, Zoe Knox bridged the divide between the Superpowers in her examination of how both sides demonized Jehovah's Witnesses as either Communists or Christians, transforming Witnesses into a universal other within both societies.

The workshop affirmed the critical need to integrate religion into academic scholarship on the Cold War, and suggests avenues for future research. First, Samuel Moyn has suggested that the late 1970s marked the dawn of a human rights moment in world history, one which challenged all modern states by making universal demands. The greater prominence of human rights talk threatened to upend established foreign policy and diplomatic practices, and exposed countries to greater scrutiny of their domestic human rights records. At the same time, both Superpowers harnessed human rights language to criticize their rivals' practices and defend their own. The role of religion in this dynamic remains underappreciated, in particular in regard to how individuals, clergy, and religious organizations adopted and adapted human rights language to navigate the landscape of the Cold War. Second, while the workshop focused on the Protestant dimensions of the Cold War, future scholars will want to consider a comparative framework that looks for commonalties between Protestantism and other religious communities. This workshop offers a viable starting place for further exploration of these and other issues. 